\title{
Comparing grades in online and face-to-face writing courses: Interpersonal accountability and institutional commitment
}

\author{
David Alan Sapp \\ Fairfield University, david.sapp@Imu.edu \\ James L. Simon \\ Fairfield University, jsimon@fairfield.edu \\ Follow this and additional works at: https://digitalcommons.fairfield.edu/english-facultypubs \\ Copyright 2005 Elsevier \\ NOTICE: this is the author's version of a work that was accepted for publication in Computers \\ and Composition. Changes resulting from the publishing process, such as peer review, editing, \\ corrections, structural formatting, and other quality control mechanisms may not be reflected in \\ this document. Changes may have been made to this work since it was submitted for \\ publication. A definitive version was subsequently published in Computers and Composition, \\ 22(4), 471-489. DOI\# 10.1016/j.compcom.2005.08.005
}

\section{Peer Reviewed}

\section{Repository Citation}

Sapp, David Alan and Simon, James L., "Comparing grades in online and face-to-face writing courses: Interpersonal accountability and institutional commitment" (2005). English Faculty Publications. 60. https://digitalcommons.fairfield.edu/english-facultypubs/60

\section{Published Citation}

Sapp, David \& Simon, James (2005). "Comparing grades in online and face-to-face writing courses: Interpersonal accountability and institutional commitment." Computers and Composition, 22(4), 471-489.

This item has been accepted for inclusion in DigitalCommons@Fairfield by an authorized administrator of DigitalCommons@Fairfield. It is brought to you by DigitalCommons@Fairfield with permission from the rightsholder(s) and is protected by copyright and/or related rights. You are free to use this item in any way that is permitted by the copyright and related rights legislation that applies to your use. For other uses, you need to obtain permission from the rights-holder(s) directly, unless additional rights are indicated by a Creative Commons license in the record and/or on the work itself. For more information, please contact digitalcommons@fairfield.edu. 
Sapp, D., \& Simon, J. (2005). Comparing Grades in Online and Face-to-Face Writing Courses: Interpersonal Accountability and Institutional Commitment. Computers and Composition, 22.4: 471-489

\section{Introduction}

In higher education, one of the attractions of online teaching (e.g., distance education, elearning, Web-based learning) is its potential to serve diverse and hard-to-reach student populations. Many universities encourage faculty to develop online courses in order to address issues ranging from limited classroom and dormitory space to limited funds. In fact, several universities now require their undergraduate students to take at least one online course each academic year (Young, 2002). There is a widely-held belief that online courses are cheaper to deliver than equivalent face-to-face courses and that they can help universities access tuition revenues from otherwise untapped markets.

The resulting shift from face-to-face classroom interactions to learning that takes place in online contexts has presented a range of challenges to students, teachers, and writing program administrators alike. Many of these challenges have been documented by educational researchers dedicated to promoting pedagogically sound and measurable learning outcomes (see Buckley, 1997; Carnevale, 2002; Hailey, Grant-Davie, \& Hult, 2001; Levitch \& Milheim, 2003; Olina \& Sullivan, 2002; Pagnucci \& Mauriello, 1999; Savenye, Olina, \& Niemczyk, 2001). One of these challenges is to protect the integrity of the grading process by discouraging any systematic difference in grading based on course delivery. In this article, by comparing grades that students receive in online and face-to-face writing courses at our university, we seek to highlight some of the differences we found in grading patterns and retention rates in two widely offered college writing courses. Then we offer some specific recommendations that argue for increased interpersonal accountability between teachers and students and increased institutional commitment to high quality online education. 
One of the most discouraging symptoms of distance education seems to be the disproportionately high student dropout rate compared to face-to-face learning contexts (Bishop, 2002; Spitzer, 2001). In addition to high student attrition (i.e., students who do not complete courses do not earn passing grades), students in online courses often report higher levels of dissatisfaction than students enrolled in equivalent face-to-face courses (Shermis, Mzumara, Olson, \& Harrington, 2001). Other researchers add that online courses tend to leave students with higher instances of unfinished learning goals, a sense of decreased importance of teacher feedback, and a lack of engagement in the learning process (Allgood, 2001; Monroe, 2002). One of the most alarming differences between online and face-to-face learning, and the one on which we focus primarily in this article, concerns inconsistencies that can occur in the assessment of student work. Our study indicates that students are consistently less likely to earn passing grades due to drop out, failure to complete, or faculty evaluation in online sections of two writing courses compared to face-to-face sections of the same courses.

There is substantial research on educators' struggles to assess student work in face-toface contexts (Imber, 2002; Muirhead, 2002; Soles, 2001). However, existing research about the assessment of student work in online contexts seems narrowly focused on the development of grading software and automated essay graders in distance education venues (e.g., Guskey, 2002). We assert that research about grading issues in online writing courses should consider variables such as accuracy and fairness in assessment, the importance and nature of teacher and peer feedback, and instructional measures that support grading processes, all of which remain important in the move from face-to-face to online teaching. Further, research on grading in online courses should be better connected to the broader discussion of high student attrition. There are common conceptual and philosophical issues related to grading across all learning contexts, and online writing courses present both continuing and new concerns about grading. 
In the first half of this article, we compare the grades students receive in online and faceto-face writing courses at our university. In addition, we review survey data collected from students in the online courses and discuss challenges in online assessment. In the second half of this article, we provide seven strategies that teachers can utilize to address the problems we discuss in online writing courses. We intend these strategies to be relevant to writing program administrators promoting online courses as well as to teachers designing learning experiences in online settings. These strategies also may be relevant to teachers who are introducing distance learning components in hybrid face-to-face courses.

\section{The "thrive or dive" phenomenon in online writing courses}

As two writing program directors at a comprehensive university located in New England, we regularly participate in the process of generating data for the purposes of outcomes assessment. As part of this task, we review students' degree audits, documents that include lists of writing courses that students complete along with the grades they receive. While we admit that grades may not accurately measure student learning, systemic discrepancies in course grades can cause alarm for program administrators like us (see Imber, 2002), especially if the discrepancies can be linked to a variable like mode of presentation.

During a recent review of two undergraduate writing courses (i.e., first-year composition and business writing), we noticed a sharp difference in the grades students received that seemed to correlate to the type of course delivery used. When comparing grades students received in face-to-face courses with grades students received in equivalent online courses, we discovered the following: In the four online courses examined, thirty percent of students did not complete the courses on schedule; that is, they withdrew, received incompletes, or failed the courses. In contrast, none of the students in five equivalent face-to-face courses failed to complete the course (see Table 1). This pattern is consistent across both writing courses we examined. 


\section{[INSERT TABLE 1]}

For this study, we selected first-year composition and business writing courses because these two courses are delivered both online and face-to-face in the English department at our university, and because they are two courses identified by writing program administrators as likely to generate high student demand in the future. The results were generated from nine sections of two writing courses: two sections of the online business writing course, three sections of the business writing course taught face-to-face, two sections of the online first-year composition course, and two sections of the first-year composition course taught face-to-face. In an attempt to control for teaching style, we selected sections of these courses in which a single teacher taught all five business writing sections, both online and face-to-face, while a different teacher taught all four sections of first-year composition. Both teachers reported using similar assignments, texts, and instructional practices for online and face-to-face courses; however, in future studies, independent observations could be utilized to confirm these claims.

In addition to our discovery that the percentage of students completing online courses is lower than those in face-to-face writing courses, we also noted that in equivalent face-to-face courses, students tended to receive higher final grades compared to their online counterparts (see Table 2). For example, $52 \%$ of the students in face-to-face sections of business writing received a final grade in the "A" range, while only $32 \%$ of the students received such a grade in online sections of this course with the same teacher. In addition, $65 \%$ of the students in face-to-face sections of first-year composition received a final grade in the "A" range, while $22 \%$ of the students received such a grade in online sections. It should be noted that we do not intend to ignore issues of grade inflation in our analysis; however, since the same teachers taught online and face-to-face sections of the same courses in the same time frame, we assume that grade 
inflation tendencies would be equivalent in these cases, an assumption that certainly deserves further study considering the grades students received in these face-to-face writing courses.

\section{[INSERT TABLE 2]}

Upon closer examination of the data, we concluded that students enrolled in online writing courses were more likely to "thrive or dive," a phrase we began to use to describe the online sections in which most of the students received final grades bunched at either the top or the bottom of the range (see Table 3 ). In other words, students in online courses were nearly as likely to receive a grade of A, A-, or B+ (38\%), what we and most students would consider "thriving," as they were to either withdraw, receive a grade of D or F, or take an incomplete in the course (33\%), that is, "diving." Students in face-to-face courses, by comparison, all either thrived (83\%) or "survived," that is, they received a grade ranging from B to C- $(17 \%)$. Not one student "dived" by receiving a D or F. This striking discovery prompted us to seek possible causes of this outcome, not only because we felt an obligation to our students for our grading policies and practices, but also because we suspected that our data might be generalizable to the increasing numbers of online writing courses our university plans to offer in the near future.

\section{[INSERT TABLE 3]}

In order to continue our investigation, we distributed surveys to students enrolled in online sections of the business writing course (see Appendix A). We also began to ask ourselves and our faculty questions regarding the data we collected during our review of grades. Because these questions might be useful to other program directors as they assess their online writing courses, we provide some of them as follows:

- Are the writing courses we offer in face-to-face and online settings taught by the same or similar faculty members?

- Are part-time teachers, who may be somewhat less invested in institutional issues, more or less likely to teach our online courses? 
- Are the class size limits similar in our face-to-face and online courses (and are they enforced)?

- How do class sizes correlate with the amount of time faculty devote to each student?

- Do online and face-to-face courses use the same or similar grading standards?

- Are the learning objectives and expectations consistent across writing courses in both settings?

After careful review of the responses to these kinds of questions, we determined that the cause of grade discrepancies in writing courses at our university do not seem to be the result of courses being offered by different faculty, using different textbooks, assignments, or learning objectives in face-to-face versus online educational settings. One of the primary reasons for the differences in the grades students receive seems to be that the student dropout rate in online writing courses is significantly higher than it is for students in equivalent face-to-face courses. In other words, we discovered a relationship between grading patterns and dropout rates. During interviews with teachers of online courses at our university, we learned that high-performing students tend to complete online courses; however, many other students disappear, some without formally dropping the courses, and these students all receive failing grades. Marginally performing students in face-to-face courses, by contrast, tend to withdraw early in the semester; under extreme circumstances, students can arrange late withdraw rather than receiving a D or F.

\section{Student voices about online learning}

There is an extensive body of literature on retention and assessment in face-to-face learning contexts, and some published studies on student retention in online education. Our initial review of this literature yielded some unsurprising conclusions. For example, Carnevale (2002) reports a study in which students enrolled in online sections of a course at Michigan State University did not perform as well as students who took the same course in face-to-face 
classrooms. Although the researchers at MSU used a content-based exit examination instead of comparing final course grades to measure their students' performance, some of the reasons why their students performed poorly in online courses resonated with our experiences. These reasons included lost motivation, institutional failure to recognize excused absences, and increased student dropout (see also Guskey, 2001; Sapp, 2003; Visser, Plomp, Amirault, \& Kuiper, 2002).

Mellon (2003) asks whether or not the learning styles of all students are necessarily compatible with the online delivery of education. He points out that many students seem to struggle to succeed in settings in which teachers cannot rely on face-to-face interaction to motivate students and build rapport. Spitzer (2001) agrees, pointing out the obvious: "Fancy graphics alone cannot sustain student interest and motivation for long” (p. 52). Clearly, not all students are prepared to meet learning objectives in online contexts. In order to do so, students must show extraordinary self-discipline and initiative: "Students who lack these abilities are not likely to do well in online courses" (Kearsley, 2002, p. 41).

The online experiences of some of our students seem to be consistent with these scholars' assertions. For example, two students who received an "A" in the online business writing course stressed the flexibility they enjoyed in the online environment:

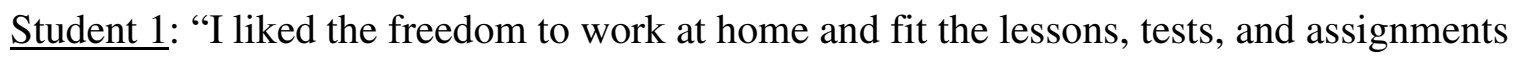
into my schedule. Many times I would write a portion of a paper and run down to throw a load of wash into the dryer... The thing I enjoyed the most were reading the discussion sessions from the other students. Although nothing can take the place of a lively class discussion, this format was great!"

Student 2: "This particular online format was very intense if the student takes it seriously. I felt like I was in running mode during the entire course. Also, if you don't keep up with the assignments, you didn't stand a chance of catching up and doing a decent job." 
Students who earned lower grades were less enthusiastic, and they often pointed to personal limitations to explain why they did not enjoy the format:

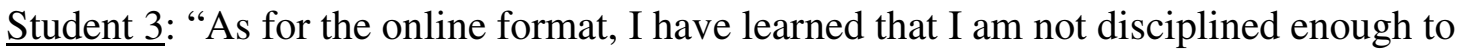
take a class in this format. I prefer the structure and attention that is required by [face-toface] classroom learning. I found that I learn more by reading a chapter and then sitting in class, listening to an instructor and taking relevant notes.... It seems to me that, even with the 'threaded discussions,' there is less brainstorming or less of a free exchange of ideas." Some of the students argued that an average time demand of 10 hours per week in the online course was excessive:

Student 4: "I felt that the workload demand somewhat defeated the purpose and convenience of taking an online course. Although I am foreign as to whether all online courses call for this type of attention, I would probably have to say that it [will] be my last time taking one due to its high time-demand."

This comment confirms our suspicion that some students believe online courses will be easier and less demanding, despite evidence to the contrary (e.g., lower average course grades).

Our survey of students in online sections (see Appendix A) reveals that the majority of students do not feel the online environment facilitates their getting to know their teachers (53\%) or fellow students (79\%). One student's comments illustrate very well our assertions regarding interpersonal accountability and mutual responsibility:

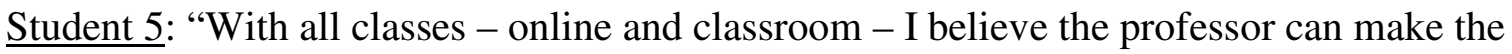
class enjoyable and challenging. My professor was great. I have only taken one online class so far, so I cannot compare the professor's ability to others. Online classroom instruction is a wonderful form of instruction - but the student and teacher still have to work together to achieve the same goals as regular classroom instruction. This is tricky." 
These students' reflections about online learning make clear the need for further research about online versus face-to-face teaching and learning, as well as vigilance to develop functional and successful pedagogical approaches.

\section{The need for interpersonal accountability in online writing courses}

In early research about distance education, high student dropout rates were reported in audio-conference courses and tele-courses (MacGregor, 2002). Some of the literature we reviewed supports our own initial reservations about online writing courses, such as Spitzer's belief that procrastination in students can increase online due to the lack of a "human mediator" in learning, one who can provide "relevance, personalization, responsiveness, and flexibility" (2001, p. 52). We believe that this challenge seems particularly relevant to our argument for increased interpersonal connections among teachers, students, and writing program administrators in higher education and is not exclusive to online learning. There are, in fact, broad differences inherent in the delivery of online and face-to-face writing courses, differences that do not seem to be connected to our specific institution. The advantages and potential challenges concerning online delivery of courses seem to be related to significant differences between teacher-student interpersonal contact and mutual accountability in online courses. Unfortunately, some students (and teachers) may be more interested in using technology to make courses efficient and, as a result, care more about minimizing their effort than mastering content (Allgood, 2001).

Some researchers suspect that the high dropout rates, and subsequent lower average grades received, among students enrolled in online courses result from lower levels of commitment on the part of students and faculty alike. We tend not to agree with these assertions. At our university, unlike many colleges and universities with more diverse student populations, the students who enroll in our online writing courses tend to be the same students who enroll in 
our face-to-face courses. These students typically enroll in some of their courses in face-to-face settings and others in online settings, perhaps to free up their daily schedules for writing internships and other activities, to try something new, or because they believe online courses to be easier. Obviously, at other institutions, geographical constraints and scheduling conflicts can be primary reasons for taking online writing courses (MacGregor, 2002; Mason, Duin, \& Lammers, 1994). Regardless, we still need to ask why some students are thriving in online settings and others are dropping out or otherwise failing to complete online writing courses.

Russell (2001) points out several potential problems with the way online education and distance learning are currently being delivered, including the quality of current online education, the absence of body language cues associated with face-to-face learning, and the degree to which socialization creates a cohesive and supportive learning environment. While Russell's study is focused primarily on secondary students, some of these concerns seem relevant to college-level writing courses, as well. For example, Russell points out that there seems to be a risk that online educators "may be tempted to cut corners" (p. 56). This may be particularly true at institutions that assign overworked part-time teachers to teach a majority of the online writing courses or, like our institution, where such courses are often taught by full-time faculty as "overloads." Russell also points out that "virtual classrooms exclude many details such as facial expressions or body language that the teacher has traditionally used to gauge understanding" (p. 56). Without the visual or auditory anchors, many students - especially those taking their first online courses—can become disoriented (see Spitzer, 2001). Also, Russell believes that "students do not always value education primarily because of its academic content. For many, it is rather an opportunity for them to meet their friends and socialize" (p. 57; see also Savenye at al., 2001). We believe increased interpersonal contact between teachers and students (and among students) is necessary. Although distance education creates opportunities for socialization through e-mail, 
online chats, and other computer-mediated interactions, these forms of interaction may be inadequate to simulate real-time interaction, to provide the interpersonal camaraderie that increases student motivation to learn, or to prepare students, including adult learners, for realworld professional settings. In this sense, education—even online education—is (and must be) more than the delivery of content; it also is the purveyor of the social skills necessary for living satisfying and productive personal and professional lives, for interacting and working with others.

Perceptions of teacher empathy, credibility, competence, and trust seem to be positively correlated to student satisfaction (Jaasma \& Koper, 1999). Technology can, of course, affect interpersonal teacher-student relationships. Some scholars, such as Atamian and DeMoville (1998), argue that the increased use of technology in education leads to a reduction in perceived teacher immediacy and trustworthiness. They contend that the often haphazard implementation of technology prevents relational payoff in the classroom, denying teachers opportunities to establish rapport with students. Complicating matters is the fact that some writing teachers who are now being encouraged to develop online courses have little experience communicating online with students, except perhaps by e-mail, an asynchronous form of discourse that approximates letters more than conversations. While many writing teachers may have the skills to communicate content and assignment instructions to students online, few have the sophisticated communication skills necessary to connect with students interpersonally, to build trust and rapport in unfamiliar virtual environments. This situation may be complicated by the written form of discourse where increasingly litigious climates cause teachers to be cautious and even cryptic in written communication. Emotional factors such as "caring" between teachers and students, while certainly not impossible to communicate in online settings, can be more difficult to achieve and to express effectively and appropriately online. 
McKeage (2001) asserts that the skills used in leading face-to-face classroom discussion do not necessarily translate into computer-mediated discussions. For example, the "fascination factor" many students experience, which is typically associated with perceptions of teacher enthusiasm in face-to-face classrooms, can be reduced in online settings. Additionally, Soles (2001) argues that one of the elements lacking in teacher-student interaction online relates to encouragement. Students learn more effectively when teachers' feedback praises "those aspects of their work that deserve praise and criticize[s] weaknesses constructively, in a voice that suggests that the student's work can and will improve with some extra effort" (p. 123). Without these important vocal cues which are more difficult to simulate online, grading can seem callous and may silence, inhibit, or discourage students. As we know, student writing is often much more personal than student work on exams, and therefore the tenor of instructor critique requires much more attention from writing teachers than from teachers of other subject matter. Moreover, Soles believes that it is essential for teachers to communicate grading criteria, be available to respond to student concerns, and share successful grading practices with colleagues.

For a variety of reasons, online courses have a reputation for being easier than their faceto-face equivalents, so it may be reasonable to conclude that many grade-driven students may be attracted to online courses that they suspect require less work. However, as we have found, students in online courses tend not to receive better grades than students in traditional courses (see also Smith, 1994). Moreover, we wonder if it might be easier for teachers to give students low or failing grades on assignments or in writing courses offered in online settings due to the reduced personal contact. In our data, teachers assigned more low grades in online than face-toface courses; more research is needed to determine teacher attitudes about this fact and to better understand the impact of grade inflation in online and face-to-face courses. 
Without the kind of interpersonal rapport typically established in face-to-face writing courses, teachers may lack a certain empathy and appropriate subjectivity in their assessment of student performance. For similar reasons, grade appeals and tendencies for others (e.g., parents, administrators, counselors) to get involved when students fail online courses may be affected because teacher assessment is less likely to be taken personally by the student. Thus, the diminished interpersonal nature of student-teacher interaction in online settings may also affect the teacher's sense of risk when assigning a failing grade. Many times, students who fail online writing courses "disappear" in a more permanent sense than students in face-to-face courses do. The fact that it may be easier to give a failing grade to a student who is not likely to be waiting outside the teacher's office door makes us wonder if there may be a systematic lack of investment in these "invisible" students on the part of faculty.

\section{Recommendations for teachers of online writing courses}

Educational researchers have recommended various strategies to assist teachers in online learning contexts, writing and otherwise. For example, Levitch and Milheim (2003) stress the importance of teachers promoting a strong sense of community in online learning contexts and point to ways students at risk of dropping out of courses can benefit from positive feedback from their teachers. Also, Northrup (2001) asserts that increased interaction among teachers and students (as well as among students themselves) helps students engage in online learning contexts. In sum, interaction seems to assist students in overcoming feelings of isolation.

The following recommendations, gleaned from the literature as well as from our own experiences, are intended to address concerns about teaching online writing courses, specifically the increased likelihood that students will not complete courses. Some of these recommendations are general while others are specific to writing courses.

\subsection{Expand orientation and "ice breaking" sessions}


This study highlights the number of students who fail to complete online writing courses due to dropout or failure. As is the case in traditional face-to-face classrooms, it is equally important to build a sense of community in the online classroom (see Northrup, 2001). Teachers should provide "ice-breaker" sessions with students in online writing courses as many of us do in our face-to-face ones. Such orientation sessions can provide students with opportunities to learn about course objectives, establish norms for course participation, and learn something about their teachers and peers. Some teachers achieve this in online writing courses by distributing lists of students including contact information or providing space online for student web sites. In some cases, students are encouraged to share pictures of themselves or pictures of something they want to be identified with. Having some knowledge about their classmates and interpersonal rapport can be important facilitators of the peer critique process and increase investment among each other and by instructors.

Hoping to better engage students, teachers can also connect with online writing students early in the semester by calling them on the telephone. Spitzer (2001) points out that calling students at the beginning of the semester makes them feel welcome (p. 53). Wallace and Wallace (2001) believe that computer-mediated voice communication will eventually serve this purpose; however, it has not yet reached the quality of the telephone. In the online delivery of the business writing course we describe in this article, the teacher calls students on the telephone to welcome them to the course and allay fears. He then encourages students to post biographical sketches on the class discussion board to introduce themselves to their classmates. Other teachers believe that periodic phone conversations throughout the semester can help students maintain engagement in course content and decrease the risk of student dropout. Expanding these types of orientation and “ice breaking” sessions can also increase students' investment in the learning process.

\subsection{Build in face-to-face meetings}


In addition to occasionally hearing their teachers' voices, students often respond positively to face-to-face meetings during the semester. Such meetings might help address the kind of concerns voiced earlier in this article by Student 3, who said he preferred "the structure and attention that is required by [face-to-face] classroom learning." While teachers, students and writing program administrators debate the merits of online versus face-to-face learning, some educational researchers conclude that the hybrid approach to online teaching (i.e., a combination of technology and human intervention) is most effective in avoiding many of the challenges we discuss in this article. According to Young (2002), "[h]ybrid models appear less controversial among faculty members than fully online courses" (p. A33), yet limitations of geography - and student interest - can complicate well-meaning efforts. For example, the teacher in our university's online business writing course invites students to optional meetings on campus, but during a recent semester only one student attended these meetings. In response to the invitation, one student responded by e-mail: “This is why we took the course online; we don't want to come to campus and meet at a set time." Despite such resistance, options for face-to-face interactions should be available (and encouraged) in order to increase the chances of student success.

\subsection{Build in accountability in course performance and grading, both for students and teachers}

Online learning often assumes that students are self-directed. We believe that this may be a false assumption. While there are successful students such as our Student 1, who "liked the freedom to work at home and fit the lessons, tests, and assignments into [her] schedule," online learning requires personal discipline, and many students are not prepared for the responsibility of acting as "partners in the teaching-learning process" (Ali \& Franklin, 2001). The need for partnership is underscored by Student 5, who notes "online classroom is a wonderful form of instruction—but the student and teacher still have to work together to achieve the same goals as regular classroom instruction. This is tricky." 
Teachers can facilitate a sense of accountability among class members by encouraging (or requiring) team projects and promoting peer critique sessions. The business writing students interviewed in this study reported that group writing projects transformed the class and enriched the learning experience. Such strategies can make students invested in each other rather than existing as autonomous workers. Writing teachers can stress the increased need for time management skills and recognize multiple ways that students can participate, from group projects and discussion board postings to sending e-mails to classmates with relevant articles and studies attached. Teachers should make sure that quality and quantity of participation are components of the grade so that students have an incentive to participate, especially given that student writers can benefit so much from peer critiques. We believe that this participation subsequently or concurrently leads to increased motivation, investment in the learning objectives, and sense of mutual accountability; however, these conclusions require further research in online settings. Moreover, these modes of participation in the class are all important new genres of writing in which students must become proficient in order to be successful in the contemporary workplace. Thus, writing teachers can explore the discursive and formalistic aspects of these writing genres as part of instruction.

Students are not the only participants who need to be motivated. Writing teachers can also become indifferent or lazy because they do not see their students in online courses. Thus, it is important that they carefully prepare written comments to their students, facilitate dialogues between themselves and students (and among students themselves), and be caring, honest, and fair about their assessment strategies.

Another challenge is that, until online education is wholeheartedly accepted into the mainstream, many of its teachers may fear negative assessment from their colleagues. One frequent criticism seems to involve grading issues. In other words, if writing teachers working in 
online settings have too many "thriving" students, they appear to lack rigor or be too lenient (see Peterson, 2001); as a result, their peers may feel that educational standards are not being met. Similarly, when too many students fail or fail to complete an online course, the teacher's abilities may be questioned. In many cases, overworked teachers, such as adjunct teachers who may teach numerous online courses, face situations in which they have to grade rapidly and be "more or less generous than they would be if they had time they need to grade fairly and objectively" (Soles, 2001, p. 132). The situation currently creates a double bind for teachers of online writing courses.

We note with interest and concern the growing interest in development of grading software and so-called automated essay graders that claim to increase rigor and fairness in evaluation. However, these systems also tend to decrease the personal connection necessary between writing students and their teachers. During the last decade, there has been a move toward utilizing essay grading software over "human rating systems" (Shermis et al., 2001, p. 250). As a result, writing students seem to be at even more risk of isolation. While educational researchers may argue that using computer software and other electronic assessment techniques increases objectivity and fairness, we argue that teacher expertise is the legitimate basis for subjective assessment of a student's written work. Moreover, teachers must be responsible for more than justifying grades and being equitable to all students (responses more to fears of student complaints and potential litigation than to legitimate pedagogical objectives). Teachers should also find ways to communicate a sense of caring for students through their assessment practices in online education as they are accustomed to doing in face-to-face settings. In addition to issues of fairness and equitability, the grading of writing also requires "careful planning, thoughtful judgment, a clear focus on purpose, excellent communication skills, and an overriding concern for the well-being of students" (Guskey, 2001, p. 780). Assigning a poor or marginal 
grade on an assignment in an online writing course should not become an excuse for a student to drop the class but an opportunity for growth and learning.

While there is some evidence that the instructors in this study employed our first three recommendations to varying degrees, our data indicates that these efforts may not be sufficient to address student dropout and failure in online writing courses. For example, the online writing teacher's practice of calling each student on the telephone at the beginning of the semester may not have been enough to sustain student engagement during the 15-week semester. In addition, while students are encouraged in online writing courses to attend occasional face-to-face meetings with the instructor (or their peers) to increase the amount of perceived support they feel as participants in a community of learning, some students resist such strategies, arguing that face-to-face meetings negate the benefits they seek by enrolling in online writing courses to begin with. While we remain confident that these three recommendations can be effective with many students enrolled in online writing courses, further research needs to verify that these strategies produce the desired outcomes most of the time. We acknowledge that additional strategies must be implemented; thus, we offer the following additional recommendations.

\subsection{Incorporate real-time online activities}

While many writing teachers successfully negotiate asynchronous communication (e.g., e-mail, bulletin board discussions) with their online students, there seems to be less evidence of successful synchronous communication (McKeage, 2001, p. 32). Especially when face-to-face meetings are not logistically possible, teachers should attempt to incorporate real-time online activities in online writing courses. Interactive chat sessions, online office hours, and video or voice messaging encourage student investment and provide opportunities for students to connect with one another. Increased opportunities are necessary for students to interact by logging on simultaneously. Little such effort was made in the online writing courses examined in our study. 
It is not enough for teachers to assign writing students to contribute to electronic discussion boards or e-mail lists. Atamian and DeMoville (1998) point out that the use of e-mail can create an impersonal teacher-student relationship. One response to this challenge is to create a chat environment like a virtual coffee lounge (Spitzer, 2001, p. 54), a place where students can meet regularly, with or without the teacher in attendance. In this vein, the use of online office hours is increasingly popular in online education (Sapp, 2003) and can provide writing students with virtual space to exchange ideas, ask questions, resolve disagreements, negotiate work, just stay in touch, or get to know one another interpersonally. McKeage (2001) points out that online office hours can also be used early in the semester to "conduct 'getting to know you' exercises" (p. 33). Students can gain familiarity with their peers while participating in two-way, collaborative learning. Other benefits to online office hours include increased accessibility to teachers for students. The interactive quality of a conversation can be achieved better in real-time communication than by e-mail.

\subsection{Be vigilant in student retention efforts}

Given this study's central finding that many students "dive" by failing to finish online courses, teachers must work harder to encourage writing students to stick with online courses. Without attendance requirements, Loomis (2000) points out that students lacking time management skills may also lack the self-discipline necessary to succeed in online courses. Teachers should provide prompt feedback on written assignments because lag time can feel longer in online settings (see also Peterson, 2001). Slow responses from writing teachers are magnified by computer-mediated communication, especially as students increasingly rely on the likes of instant messaging for their interpersonal communication. They should be responsive to student correspondence, and they should realize that feedback (not only the grade) is even more important in online learning contexts because students are at greater risk for disengagement. It 
can be effective for writing teachers to solicit feedback from students about the course. A simple technique like mid-term evaluations can help writing teachers identify students in jeopardy and allow those students enough time to make up their deficiencies.

\subsection{Insist upon institutional support}

Teachers may find that online writing course require more time, not less, to design than conventional courses. As universities become more eager to expand their online course offerings, administrators should be encouraged to invest in faculty members willing to meet this demand. Faculty development workshops and ongoing support networks for online writing teachers should be encouraged (see Savenye et al., 2001). For example, we discourage anyone from attempting an online writing course without strong computer backup support. Platforms like WebCT can help avoid the drudgery involved in adapting courses online, freeing teachers to be more inventive with instructional approaches. Universities should be encouraged to provide such a platform so that quiz and test materials, chat rooms, peer review sessions, discussion boards, and other ways to facilitate communication are available and easy to understand for teachers and students alike. Many leading writing textbooks already come with special editions tailored for these platforms, again freeing the writing teacher to build on the text (e.g., Porter, Sullivan, \& Johnson-Eilola, 2001). Additionally, the question of intellectual property ownership of faculty online course designs should be systematically addressed before a course is first offered, and university policies, protections, and agreements should be negotiated and clearly communicated.

Institutional support for the development of online writing courses can also take the form of giving high priority to maintaining the computerized backbone for these courses. At our institution, computing and network services often schedule its annual routine maintenance (i.e., downtime) in the middle of June despite the fact that there are approximately two dozen online courses running during this period. These courses, their teachers and students, lose access to 
WebCT for two days in the middle of the accelerated five-week semester, which results in disrupted teaching processes not to mention harm to the teachers' credibility (for not notifying students that their access is being disrupted) and students' confidence, many of whom believe that they have done something wrong when they are unable to access course materials.

\subsection{Maintain sensitivity to diversity issues as mediated by technology}

While our study did not adequately address this issue, we would be remiss if we failed to mention the importance of a commitment to diversity issues in online education. It has been widely argued that in traditional face-to-face classrooms, "age, race, gender, and personal [and cultural] values might influence grading" (Soles, 2001, p. 131), and composition teachers have been in the vanguard of raising these issues (e.g., Buckley, 1997). On the other hand, distance learning may provide opportunities for some writing students to compete on more equal footing than they experience in face-to-face classrooms. Introverted or shy students, for example, may actually feel empowered by using a mediator such as technology. The invisibility of students in online writing courses can break down barriers to learning such as racism, sexism, homophobia, and the social obstacles related to popularity and fashionability.

Therefore, in their efforts to overcome problems teaching in online environments, writing teachers should be careful not to eliminate some of the very reasons some students are drawn to online settings. For example, though we suggest creating opportunities for face-to-face meetings within online courses, this recommendation may pose challenges for students who are hoping to overcome social, physical, or perceptual obstacles. At the same time, teachers should be aware that teaching in online settings can complicate some of these same issues (i.e., race, gender), particularly in terms of the patterns of interaction among teachers and their students (see Belcher, 1999; Wolfe, 1999). Students looking for a safe learning environment may not find online educational environments devoid of isolation or intolerance (Hailey et al., 2001). Also, according 
to McKeage (2001), the cloak of anonymity provided by the online classroom, may in fact stifle participation; students may be even less likely to answer questions posed by teachers, to ask a peer a question, or to answer a peer's question. Students searching for a sense of connectedness or for a classroom where their identity will not be stigmatized may find it equally difficult to develop positive relations with teachers and other students in online writing courses (see Pagnucci \& Mauriello, 1999).

Wolfe (1999) argues that online classroom settings may not provide a gender-neutral learning environment for some female students. Despite popular claims to the contrary, her classroom study at the University of Texas suggests that some female students communicate less frequently (and differently) than their male classmates in the online classroom due to what can be considered confrontational or adversarial discourse by the male students that mirrored typical communication behaviors and unequal power relations embedded in face-to-face classrooms (see also Hocks, 1999). Many female students report feeling less supported and "ignored" by their male peers (p. 162). Furthermore, it should also be noted that online classrooms can, in some cases, actually produce hostile learning environments for writing students that can be experienced as even more intolerable than face-to-face settings. For example, "flaming" continues to challenge teachers and students as it does in all electronic media (e.g., chat rooms, electronic bulletin boards, e-mail listservs). Unlike in face-to-face classrooms where teachers can quickly serve as moderators of negative communication behaviors, the nature of computermediated communication slows teachers' response time to harmful communication acts directed at specific students, the teacher, or the course (Hailey et al., 2001). Delays in teacher or moderator responses can lead to writing students feeling harassed, marginalized, isolated, or threatened. 
It is worth reiterating that the discourse patterns that manifest in the increasingly ubiquitous online worlds our students inhabit present important instructional opportunities for writing teachers in particular. After all, online environments tend to be so text-based and the theories informing emerging analysis of online environments have been profoundly influenced by the intellectual work of critical theorists and literacy scholars.

\section{Conclusions}

The traditional face-to-face classroom model for the teaching of writing seems to be flanked by the increasing popularity and practical advantages of online learning. Rapid technological changes portend a continuation and probably a proliferation of this trend with implications to the assessment of student work, posing challenges for writing teachers and their students. A strong need exists for continued research concerning the implementation of Webbased learning (see also, Goldberg, Russell, \& Cook, 2003; Hewett, 2001; Yagelski \& Grabill, 1998). This article, which focuses on grading issues in online writing courses, builds upon the body of knowledge about distance education, and it argues for greater attention to grading discrepancies and the "thrive or dive" phenomenon in face-to-face and online writing courses.

Providing consistent grading across teachers is a challenge in any multi-section writing course, especially first-year writing where differences can emerge between full-time teachers and the adjunct instructors who handle the heavy teaching load in the oft-mandatory course.

Allowing additional differences in grading to emerge based on the type of course delivery can exacerbate the problem. In order to ensure that online education remains committed as much to the education of the student as to the structural and revenue advantages for the university, we must ensure that more writing students can thrive and survive, and that our learning outcomes better approximate those in our face-to-face writing courses. We hope the recommendations we offer for teachers can help them develop successful online writing courses. 
Table 1

Students completing courses on schedule, online versus face-to-face writing courses

\begin{tabular}{lcccccc} 
& \multicolumn{2}{c}{$\begin{array}{c}\text { business writing } \\
\text { online }\end{array}$} & face-to-face & $\begin{array}{c}\text { first-year composition } \\
\text { online }\end{array}$ & face-to-face & all writing courses \\
online & face-to-face \\
Completed course & $75 \%$ & $100 \%$ & $56 \%$ & $100 \%$ & $70 \%$ & $100 \%$ \\
Did not complete & $25 \%$ & $0 \%$ & $44 \%$ & $0 \%$ & $30 \%$ & $0 \%$ \\
& & & & & & \\
Total & $100 \%$ & $100 \%$ & $100 \%$ & $100 \%$ & $100 \%$ & $100 \%$ \\
$\mathrm{n}$ & 28 & 31 & 9 & 40 & 37 & 71
\end{tabular}


Table 2

Grade distributions, online versus face-to-face writing courses

\begin{tabular}{|c|c|c|c|c|}
\hline \multirow[b]{2}{*}{ Grade } & \multicolumn{2}{|c|}{ business writing } & \multicolumn{2}{|c|}{ first-year composition } \\
\hline & online & face-to-face & online & face-to-face \\
\hline $\mathrm{A} / \mathrm{A}-$ & $32 \%$ & $52 \%$ & $22 \%$ & $65 \%$ \\
\hline $\mathrm{B}+/ \mathrm{B} / \mathrm{B}-$ & $25 \%$ & $45 \%$ & $33 \%$ & $35 \%$ \\
\hline $\mathrm{C}+/ \mathrm{C} / \mathrm{C}-$ & $14 \%$ & $3 \%$ & $0 \%$ & $0 \%$ \\
\hline $\mathrm{D}$ & $4 \%$ & $0 \%$ & $0 \%$ & $0 \%$ \\
\hline $\mathrm{F}$ & $11 \%$ & $0 \%$ & $0 \%$ & $0 \%$ \\
\hline Incomplete & $11 \%$ & $0 \%$ & $33 \%$ & $0 \%$ \\
\hline Withdrew & $4 \%$ & $0 \%$ & $11 \%$ & $0 \%$ \\
\hline Total & $101 \% *$ & $100 \%$ & $99 \% *$ & $100 \%$ \\
\hline $\mathrm{n}$ & 28 & 31 & 9 & 40 \\
\hline
\end{tabular}

*Percentages do not add up to $100 \%$ due to rounding 
Table 3

Thrive, survive, or dive: a comparison of online versus face-to-face writing courses

\begin{tabular}{lcc} 
& online & face-to-face \\
"Thrive" (A, A-, B+) & $38 \%$ & $83 \%$ \\
"Survive" (B, B-, C+, C, C-) & $29 \%$ & $17 \%$ \\
"Dive" (D, F, I, W) & $33 \%$ & $0 \%$ \\
\hline Total & & $100 \%$ \\
n & $100 \%$ & 71
\end{tabular}




\section{References}

Ali, Ahmed, \& Franklin, Teresa. (2001). Internet use in the classroom: Potential and pitfalls for student learning and teacher-student relationships. Educational Technology, 41(4), 57-59.

Allgood, Sam. (2001). Grade targets and teaching innovations. Economics of Education Review, 20, 485-493.

Atamian, Rubik, \& DeMoville, Wig. (1998). Office hours—none: An e-mail experiment. College Teaching, 46(1), 31-35.

Belcher, Diane. (1999). Authentic interaction in a virtual classroom: Leveling the playing field in a graduate seminar. Computers and Composition, 16, 253-267.

Bishop, Wendy. (2002). Wendy Bishop on teaching with technology. Interview by Sonja Bagby. Kairos: Rhetoric, Technology, Pedagogy, 7(3). Available: <http://english.ttu.edu/kairos/7.3.htm> [Accessed: 4 March 2004].

Buckley, Joanne. (1997). The invisible audience and the disembodied voice: Online teaching and the loss of body image. Computers and Composition, 14, 179-187.

Carnevale, Dan. (2002, March 15). Online students don't fare as well as classroom counterparts, study finds. The Chronicle of Higher Education, A38.

Goldberg, Amie, Russell, Michael, \& Cook, Abigail. (2003). The effect of computers on student writing: A meta-analysis of studies from 1992 to 2002. The Journal of Technology, Learning, and Assessment, 2(1), 1-52.

Guskey, Thomas R. (2002). Computerized grade books and the myth of objectivity. Phi Delta Kappan, 83(10), 775-780.

Guskey, Thomas R. (2001). Helping standards make the grade. Educational Leadership, 59(1), 20-27.

Hailey, David E., Jr., Grant-Davie, Keith, \& Hult, Christine A. (2001). Online education horror 
stories worthy of Halloween: A short list of problems and solutions in online instruction. Computers and Composition, 18, 387-397.

Hewett, Beth L. (2001). Generating new theory for online writing instruction (OWI). Kairos: Rhetoric, Technology, Pedagogy 6(2). Available: <http://english.ttu.edu/kairos/6.2.htm> [Accessed: 4 March 2004].

Hocks, Mary E. (1999). Feminist interventions in electronic environments. Computers and Composition, 16, 107-119.

Imber, Michael. (2002). The problem with grading. American School Board Journal, 189(6), 40$41,47$.

Jaasma, Margorie A., \& Koper, Randall J. (1999). The relationship of student-faculty out-ofclass communication to faculty immediacy and trust and to student motivation. Communication Education, 48, 41-47.

Kearsley, Greg. (2002). Is online learning for everybody? Educational Technology, 42(1), 41-44.

Levitch, Sharon, \& Milheim, William. (2003). Transitioning instructor skills to the virtual classroom. Educational Technology, 43(2), 42-46.

Loomis, Kenneth D. (2000). Learning styles and asynchronous learning: Comparing the LASSI model to class performance. Journal of Asynchronous Learning Networks, 4(1), 23-32.

MacGregor, Cynthia J. (2002). Personality differences between online and face-to-face students. The Journal of Continuing Higher Education, 50(3), 14-23.

Mason, Lisa D., Duin, Ann H., \& Lammers, Elizabeth. (1994). Linking learners: Structuring a mentoring via telecommunications course. Computers and Composition, 11, 123-135.

McKeage, Kim. (2001). Office hours as you like them: Integrating real-time chats into the course media mix. College Teaching, 49(1), 32-38.

Mellon, Constance A. (2003). From need to ownership: Socialization into online teaching. 
Educational Technology, 43(2), 47-50.

Monroe, Barbara. (2002). Feedback: Where it's at is where it's at. English Journal, 92(1), 101104.

Muirhead, Brent. (2002, February). Relevant assessment strategies for online colleges and universities. USDLA Journal, 16(2). Available: <http://www.usdla.org> [Accessed: 4 March 2004].

Northrup, Pam. (2001). A framework for designing interactivity into Web-based instruction. Educational Technology, 42(1), 31-39.

Olina, Zane, \& Sullivan, Howard J. (2002). Effects of classroom evaluation strategies on student achievement and attitudes. Educational Technology Research and Development, 50(3), $61-75$.

Pagnucci, Gian S., \& Mauriello, Nicholas. (1999). The masquerade: Gender, identity, and writing for the Web. Computers and Composition, 16, 141-151.

Peterson, Patricia Webb. (2001). The debate about online learning: Key issues for writing teachers. Computers and Composition, 18, 359-370.

Porter, James E., Sullivan, Patricia, \& Johnson-Eilola, Johndan. (2001). Professional writing online: User's handbook. Boston: Allyn and Bacon.

Russell, Glenn. (2001). Virtual schools and educational futures. Educational Technology, 41(6), $55-57$.

Sapp, David Alan. (2003, October). Utilizing online office hours to maximize faculty-student contact in the technical writing classroom. Paper presented at the convention of the Rocky Mountain Modern Language Association, Missoula, MT.

Savenye, Wilhelmina, Olina, Zane, \& Niemczyk, Mary. (2001). So you are going to be an online 
writing instructor: Issues in designing, developing, and delivering an online course. Computers and Composition, 18, 371-385.

Shermis, Mark D., Mzumara, Howard R., Olson, Jennifer, \& Harrington, Susanmarie. (2001). On-line grading of student essays: PEG goes on the World Wide Web. Assessment \& Evaluation in Higher Education, 26(3), 247-259.

Smith, William. (1994). Computer-mediated communication: An experimental study. Journalism Educator, 48(4), 27-33.

Soles, Derek. (2001). Grading as a teaching strategy. Teaching English in the Two-Year College, 29(2), 122-134.

Spitzer, Dean R. (2001). Don't forget the high-touch with the high-tech in distance learning. Educational Technology, 41(2), 51-55.

Visser, Lya, Plomp, Tjeerd, Amirault, Ray J., \& Kuiper, Wilmad. (2002). Motivating students at a distance: The case of an international audience. Educational Technology Research and Development, 50(3), 94-110.

Wallace, F. Layne, \& Wallace Susan R. (2001). Electronic office hours: A component of distance learning. Computers \& Education, 37, 195-209.

Wolfe, Joanna L. (1999). Why do women feel ignored? Gender differences in computermediated classroom interactions. Computers and Composition, 16, 153-166.

Yagelski, Robert P., \& Grabill, Jeffrey T. (1998). Computer-mediated communication in the undergraduate writing classroom: A study of the relationship of online discourse in two writing classes. Computers and Composition, 15, 11-40.

Young, Jeffrey R. (2002, March 22). 'Hybrid' teaching seeks to end the divide between traditional and online instruction. The Chronicle of Higher Education, A33. 


\section{Appendix A \\ Student Survey, Business Writing, Online Sections}

Why did you select this particular section of "Business Writing"? (Mark several responses, if appropriate) scheduling problems with other sections and/or courses flexibility in personal time management reputation of the teacher interest in taking an online course using WebCT thought it would be easier more comfortable working online didn't know it was going to be an online course other

What do you think are the advantages of taking online courses using WebCT?

What do you think are the disadvantages of taking online courses using WebCT?

What do your friends and/or parents think about your taking an online course at Fairfield University?

To what extent do you feel that you got to know your instructor in this online course?

To what extent do you feel that you got to know your classmates in this online course?

What do you think was the value of the required face-to-face meetings during this semester?

What final grade do you expect to earn in this course?
A
B
$\mathrm{C}$
$\mathrm{D}$
F

If you had taken this course in a traditional face-to-face format, do you think your final grade would be higher _the same_lower

If you had the option of doing so, would you consider taking another online course at Fairfield University in the future?

yes

no

unsure

Would you recommend that your friends at Fairfield University sign up for an online section of "Business Writing"? yes no no unsure

What suggestions do you have for improving online courses like "Business Writing" at Fairfield University?

Are you:

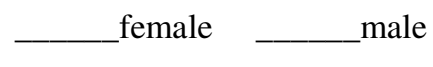
freshman sophomore junior senior other

How do you define your ethnic identity? (e.g., Caucasian, African-American, Hispanic, etc.)

Do you have any sort of physical disability? __ _ yes ___ no

For approximately how long have you owned a computer? year(s)

With what frequency did you use the internet BEFORE taking this class? multiple times per day daily weekly monthly 
less frequently

With what frequency do you use the internet SINCE taking this class?

\begin{tabular}{l} 
multiple times \\
\hline daily \\
weekly \\
monthly \\
less frequently
\end{tabular}

How would you rate your overall COMFORT LEVEL with using the computer? high moderate low

How would you rate your overall COMFORT LEVEL with using the internet? high moderate low

How would you rate your PROFICIENCY in using the computer? high moderate low

How would you rate your PROFICIENCY in using the internet? __ high moderate low 